256. Devangan, D.P. and Flower, D.R.: 1982, MNRAS 199 p. 457.

257. Devangan, D.P. and Flower, D.R.: J. Phys. B. 17 p. 2157.

258. Flower, D.R. and Guilloteau, S.: 1982, Astron. Ap. 114 p. 238.

259. Sakimoto, K.: 1982, Chem. Phys. 68 p. 155; 1982, J. Phys. Soc. Japan 51, 2657; 1983, Chem. Phys. 79 p. 137; 1984, Chem. Phys. 85 p. 273.

260. Takayanagi, K.: 1982, J. Phys. Soc. Japan 51 p. 3337.

261. Su, T. and Chesnovich, W.J.: 1982, J. Chem. Phys. 76 p. 5183.

262. Bates, D.R.: 1982, Proc. Roy. Soc. A 384 p. 289.

263. Bates, D.R.: 1983, Chem. Phys. Lett. 97 p. 19.

264. Roberge, W.G. and Dalgarno, A.: 1982, Ap. J. 255 p. 1176.

265. Blais, N.C. and Truhlar, D.G.: 1982, Ap. J. 258, L79.

266. Blais, N.C. and Truhlar, D.G.: 1983, J. Chem. Phys. 78 p. 2388.

267. Lepp, S. and Shull, M.J.: 1983, Ap. J. 270 p. 578.

268. Federman, S.R. and Shipsey, F.J.: 1983, Ap. J. 269 p. 791.

\title{
WORRING GROUP 4: STRUCTURE OF ATOMIC SPECTRA
}

\section{A. Recent Laboratory Results and Regeareh in Progress}

A Bibliography on Atomic Energy Levels and Spectra covering the period July 1979 through December 1983 is scheduled for publication in late 1984(1). The references in Table 1 are thus limited to papers published or known to be in press in 1984; the selection was made from references giving data on energy levels, wavelengths, and line classifications for spectra of the elements $z \leq 30$. S. Johansson notes that the spectra under investigation in the Physics Department of Lund University, Sweden, include S III, IV, VII, VIII, IX; Cl VI, VII, VIII, $\mathrm{X}$; Sc V; the (Ne I) isoelectronic spectra Sc XII-Fe XVII; TI I; Cr I, II, V; Fe II, III; and several high-ionization spectra of $\mathrm{NI}$, the work on Fe III and the Ni spectra being done in collaboration with researchers in the Zeeman Laboratory, Amsterdam. Term analyses in progress at the Lund Institute of Technology, as reported by $W$. Persson, include Ne III and $K$ II, III. This group has recently completed analyses for $\mathrm{Kr} I V, \mathrm{Rb} V, \mathrm{Sr} V, \mathrm{VI}$ and has papers in preparation for $\mathrm{Rb}$ IV, Y VI, and Xe II. Fourier-transform spectrometric observations at the National Solar Observatory (KItt Peak) by J. Brault and collaborators are yielding more accurate and complete line lists for the first and second spectra of several elements, including $\mathrm{Mg}, \mathrm{Al}, \mathrm{Ti}, \mathrm{V}, \mathrm{Cr}, \mathrm{Fe}$, and $\mathrm{Ni}$. Ongoing extensions of the term analyses for some of these spectra were mentioned above; similar work is underway for Mg I, II, A1 I, II, and V I, II (E. Biémont, University of Liége) and for Fe I (R. C. M. Learner, Imperial College, London). B. C. Fawcett's current research at the Rutherford Appleton Laboratory, Oxfordshire, England, includes work on the oxygen-1ike spectra P VIII through Fe XIX.

\section{B. Compilations, Isoelectronic-Sequence Observations and Predictions}

The NBS Atomic Energy Levels Data Center published energy-levels compllations for all the spectra of $\mathrm{Fe}(29)$ and $\mathrm{SI}(30)$. Revised and updated energy-levels compllations for the 235 spectra of the ten iron-group elements $K$ through $\mathrm{Ni}$ will appear in a single volume in $1985(31)$. A compilation of levels for the $P$ spectra has also been submitted(32), and C. E. Moore has prepared new tables of levels and multiplets for 0 IV and 0 III(33).

R. L. Kelly's revised compilation of atomic lines below 2000 A is scheduled for publication in 1985(34). These tables supersede a similar 1973 compilation and cover the same elements, $\mathrm{H}$ through $\mathrm{Kr}$. Fawcett's review(28) includes tables of observed forbidden lines for ions stripped to the $n=2$ and $n=3$ shells. Some of the tables of atomic wavelengths in the CRC Handbook were revised and updated for the latest edition(35); about 45000 lines from the first five spectra of all elements in all wavelength ranges are included. 
A number of papers give energy levels and/or wavelengths as observed or predicted along isolectronic sequences. Some of the predictions are sufficiently accurate to be used for line identifications in high-ionization spectra. Peacock et a1. (15) have measured wavelengths of lines of $\mathrm{Ar}, \mathrm{Ti}, \mathrm{Cr}, \mathrm{Fe}$ and $\mathrm{Ni}$ in ionization stages belonging to the $\mathrm{Li}, 0, \mathrm{~F}, \mathrm{Na}$, or $\mathrm{Mg}$ isoelectronic sequences; for the $\mathrm{F}-1$ ike and $\mathrm{Mg}-1 i k e$ lons, predicted wavelengths are listed for the elements to Mo $(Z=42)$. B. Edlén has further refined his methods to obtain accurate predictions for the $n=2$ configurations of the $L i, B e, 0$, and $F$ sequences(36), the $B$ sequence(37), the $N$ sequence (38), and the $C$ sequence(39). These papers include critical compilations of pertinent experimental results, as does Edlén's survey of magnetic-dipole lines in the spectra of ions of the elements $\mathrm{Cr}$ to $\mathrm{Ag}(40)$. Fawcett's tabulations of calculated quantities for the $\mathrm{Be}(41), F(42), \mathrm{Mg}(43)$, and $\mathrm{Al}(44)$ isoelectronic sequences include predicted wavelengths and, in most cases, experimental wavelengths for some transitions. Recent calculations by Hata and Grant(45) give predicted wavelengths for selected lines of He-like, Li-like, and $\mathrm{Be}-1$ ike ions of the elements $\mathrm{Ca}$ to $\mathrm{Cu}$. Additional references for isoelectronicsequence predictions are given in(1) and in the report of Working Group 2.

\section{TABLE 1}

Selected references on energy levels, wavelengths, and line classifications for spectra of elements $Z \leq 30$. This table is supplementary to a recent bibliography (1) and also does not include references described in Sec. II of this report.

Fe VII (2)

$\mathrm{Mg}$ I (3)

Al I (3)

A1 IV (4)

AI VIII-X (5)

Al XI (6)

Si I $(7,8)$

S I (9)

$S \operatorname{III~(10)~}$

$S$ VII (11)

C1 VII (12)

Ar IX (13)

Sc XII (14)

T1 XIII (14)

T1 XIV-XX (15)

T1 XXI, XXII (16)
V II (17)

V XIV (14)

Cr XV (14)

Cr XX, XXI (18)

Cr XXII, XXIII (19)

Fe II (20)

Fe XV (21)

Fe $\operatorname{XVII}(14,22)$

Fe XVIII-XX (15)

Co III (23)

$\mathrm{Ni} \operatorname{XIX}(14,22)$

Cu XXVI-XXVIII (24)

$\mathrm{Zn}$ IV (25)

Zn VI (26)

Zn XIV-XIX (27) 


\section{References}

1. Musgrove, A. and Zalubas, R.: 1984, Bibllography on Atomic Energy Levels and Spectra, July 1979 through December 1983, NBS Spec. Publ. 363, Suppl. 3

(U.S. Government Printing Office, Washington, D.C. 20402, U.S.A.).

2. Engström, L.: 1984, Phys. Scr. 29, p. 113.

3. Chang, E.S. and Noyes, R.W.: 1983, Astrophys. J. 275, L.11.

4. Madin, M.I.: 1983, Opt. Spectrosc. (USSR) 55, p. 336.

5. Denne, B. and Hinnov, E.: 1984, Phys. Rev. A 29, p. 3442.

6. Buchet, J.P., Buchet-Poulizac, M.C., Denis, A., Desesquelles, J., Druetta, M., Martin, S., Grandin, J.P., Hennecart, D., Husson, X. Lecler, D.: 1984, J. Phys. (Paris) Lett. 45, L361.

7. Inguscio, M., Evenson, K.M., Beltran-Lopez, V. and Ley-Koo, E.: 1984 , Astrophys. J. 278, L127.

8. Chang, E.S.: 1984, J. Phys. B 17, L11.

9. Sarma, V.N. and Joshi, Y.N.: 1984, Physica (Utrecht) 123C, p. 349.

10. Smith, P.L., Magnusson, C.E. and Zetterberg, P.0.: 1984, Astrophys. J. 277, L79.

11. Jupén, C., Litzén, U. and Trigueiros, A.: 1984, Phys. Scr. 29, p. 317.

12. Jupén, C., Fremberg, J. and Fawcett, B.: 1984, Phys. Scr. 30, p. 260.

13. Fawcett, B.C.: 1984, Phys. Scr. (submitted for publication).

14. Jupén, C., Litzén, U.: 1984, Phys. Scr. 30, p. 112.

15. Peacock, N.J., Stamp, M.F. and Silver, J.D.: 1984, Phys. Scr. T8, p. 10.

16. Bitter, M., von Goeler, S., Cohen, S., Hill, K.W., Sesnic, S., Tenney, F., Timberlake, J., Safronova, U.I., Vainshteln, L.A., Dubau, J., Loulergue, M., Bely-Dubau, F. and Steenman-Clark, L.: 1984, Phys. Rev. A 29, p. 661 .

17. Iglesias, L., Rico, F.R. and Garcia-Riquelme, 0.: 1984, Opt. Pura Ap1. 17 p. 93.

18. Burkhalter, P.G., Charatis, G., Rockett, P.D. and Newman, D.: 1984, J. Opt. Soc. Am. B 1, p. 155 .

19. Grandin, J.P., Huet, M., Husson, X., Lecler, D., Touvet, D., Buchet, J.P., Buchet-Poulizac, M.C., Denis, A., Desesquelles, J. and Druetta, M.: 1984 , J. Phys. (Paris) 45, p. 1423.

20. Johnsson, S. and Jordan, C.: 1984, Mon. Not. R. Astron. Soc. 210, p. 239.

21. Briand, J.P., Tavernier, M., Marrus, R. and Desclaux, J.P.: 1984, Phys. Rev. A 29, p. 3143 .

22. Jupén, C.: 1984, Mon. Not. R. Astron. Soc. 208, p.1.

23. Raassen, A.J.J. and Orti Ortin, S.: 1984, Physica (Utrecht) 123C., p. 353.

24. Buchet, J.P., Buchet-Poulizac, M.C., Denis, A., Desesquelles, J., Druetta, M., Grandin, J.P., Husson, X. and Lecler, D.: 1984, Nucl. Instrum. Methods (in press).

25. van Kleef, T.A.M., Joshi, Y.N. and Barakat, M.M.: 1984, Phys. Scr. 29, p. 216 .

26. van Kleef, T.A.M., Joshi, Y.N., Barakat, M.M. and Meijer, F.G.: 1984, Physica (Utrecht) 125C, p. 97.

27. Burrell, K.H., Groebner, R.J., Brooks, N.H. and Rottler, L.: 1984, Phys. Rev. A 29 , p. 1343 .

28. Fawcett, B.C.: 1984, J. Opt. Soc. Am. B 1, p. 195.

29. Corliss, C. and Sugar, J.: 1982, J. Phys. Chem. Ref. Data 11, p. 135.

30. Martin, W.C. and Zalubas, R.: 1983, J. Phys. Chem. Ref. Data 12, p. 323.

31. Sugar, J. and Corliss, C.: 1985, Atomic Energy Levels of the Iron Period Elements: Potassium through Nickel (submitted for publication as a Supplement of J. Phys. Chem. Ref. Data).

32. Martin, W.C., Zalubas, R. and Musgrove, A.: 1985 (submitted to J. Phys. Chem. Ref. Data).

33. Moore, C.E.: 1982, Nat. Stand. Ref. Data Ser., Nat. Bur. Stand. (U.S.) 3, Sec. 10 [0 IV] ; 1984, ibid., Sec. 11 [0 III].

34. Kelly, R.L.: 1985, Atomic and Ionic Lines Below 2000 Angstroms (submitted for publication as a Supplement to J. Phys. Chem. Ref. Data). 
35. Reader, J. and Corliss, C., Editors: 1984, in CRC Handbook of Chemistry and Physics, 65th Edition (CRC Press, Boca Raton, FL, U.S.A.).

36. Edlén, B.: 1983, Phys. Scr. 28, p. 51 .

37. Edlén, B.: 1983, Phys. Scr. 28, p. 483.

38. Edlén, B.: 1984, Phys. Scr. 30, p. 135.

39. Edlén, B.: 1985, Phys. Scr. (to be published)

40. Edlén, B.: 1984, Phys. Scr. T8, p. 5.

41. Fawcett, B.C.: 1984, At. Data Nuc1. Data Tables 30,1 ; ibid. 30, p. 423.

42. Fawcett, B.C.: 1984, At. Data Nucl. Data Tables (in press).

43. Fawcett, B.C.: 1983, At. Data Nucl. Data Tables 28, p. 579.

44. Fawcett, B.C.: 1983, At. Data Nucl. Data Tables 28, p. 557.

45. Hata, J. and Grant, I.P.: 1984, Mon. Not. R. Astron. Soc. (in press).

\section{W.C. Martin \\ Chairman of the Working Group}

\section{WORKING GROUP 5: MOLECULAR SPECTROSCOPY}

\section{A. Compendia. Bibliographies. Atiases}

Research in molecular spectroscopy over much of the electromagnetic spectrum has continued intensively over the past three years. It has been stimulated not only by the imperatives of fundamental research programmes in many laboratories, but also by the impact of molecular lasers on the field, and the needs of atmospheric and environmental programmes. The literature is so prolific that it is impossible even to review briefly here all that is relevant to astrophysical needs. Thus most of this report has been compiled from the contributions from individual workers and Research Centres.

The bi-monthly Berkeley Newsletter(1) complled from molecular spectroscopic publications in more than 30 journals continues to be a prime bibliographic tool for its more than 500 subscribers.

\section{B. Molecular Data}

\section{ELECTRONIC BAND ANALYSES AND CONSTANTS OF DIATOMIC MOLECULES}

Using laser spectroscopic methods Linton et al.(2) in a collaboration of workers from four laboratories, have continued their definitive studies of the $\mathrm{CeO}$ spectrum. The energles of 16 low lying states have been determined and quantum numbers assigned with certainty to 14 of them, and identification and analysis tables are provided for many bands.

Hirota and collaborators at the Institute of Molecular Science at Okazaki have an extensive programme on the microwave and infrared spectra of $\mathrm{CH}_{3}(3,4)$, $\mathrm{HO}_{2}(5), \operatorname{SiN}(6), \mathrm{PO}(7,8), \mathrm{HCCN}(9)$ and $\mathrm{FeO}(10)$. Hefferlin(11) continues his theoretical and numerical studies on the systematic properties of constants of diatomic molecules.

\section{TRANSITION PROBABILITIES, LIFETIMES, INTENSITIES}

Dressler (Zurich) reports the following experimental and theoretical studies on $\mathrm{f}-$ values, lifetimes, and transition moments for band systems of $\mathrm{NO}, \mathrm{N}_{2}$ and $\mathrm{H}_{2}$. Experimental and theoretical studies have been made on transitions between excited ${ }^{2}$ II states of NO by Gallusser and dressler(12). Similar work has been done for transitions between singlet states of $\mathrm{N}_{2}$ by Stahe1, Leoni and Dressler(13). An extensive study of lifetimes and transitions probabilities for a number of $\mathrm{H}_{2}$ states and transitions between then are also reported(14-18).

Sharp (Munich)(19) has developed an efficient computational method for numerical evaluation of Morse Franck-Condon factors and r-centroids of molecular band systems. 